\title{
An Acrostic in Horace, Carm. 3.2
}

\author{
Paul K. Hosle \\ The Queen's College, University of Oxford \\ paul.hosle@queens.ox.ac.uk
}

Received August 2019| Accepted August 2019

Horace's first Roman Ode begins with the famous verse Odi profanum volgus et arceo (Carm. 3.1.1). ${ }^{1}$ While it is widely remarked that Horace, alluding to Callimachus' pronouncement $\sigma \ltimes x \alpha \alpha i v \omega ~ \pi \dot{\alpha} v \tau \alpha \tau \dot{\alpha} \delta \eta \mu \dot{\sigma} \sigma \alpha \alpha$ (epigram 28.4 Pf.), thereby announces his own allegiance to Hellenistic aesthetics, it appears to have escaped notice from commentators ${ }^{2}$ that the opening of the following Roman Ode contains an embodiment of this Hellenistic refinement in the form of an acrostic. ${ }^{3}$

The first stanza of Horace's second Roman Ode runs as follows (v. 1-4):4

\author{
Angustam amice pauperiem pati \\ robustus acri militia puer \\ condiscat et Parthos ferocis \\ vexet eques metuendus hasta ${ }^{5}$
}

The initial letters of these four verses spell out arcu. It is notoriously not always easy to determine when an acrostic is intentional or not, but the surest

1 The Latin text of Horace is cited from Klingner 1959.

2 The detected acrostic is mentioned neither in Nisbet and Rudd $2004 \mathrm{ad}$ loc. nor in the recent general articles on acrostics that have come to my attention.

3 The technique of acrostics was inherited by Latin poets from their Hellenistic predecessors. The most celebrated Hellenistic acrostics are probably Aratus' $\Lambda$ EחTH acrostic and Nicander's acrostic signature(s), noticed first in modern times by Jacques 1960 and Lobel 1928 respectively. More generally on the influence of Hellenistic poetics on Horace, see the survey of Thomas 2007, where references are also provided to major earlier studies.

4 I follow the conventional poem division and not Heyworth 1995 and Griffiths 2002, who see the Roman Odes as in fact one single Roman Ode, 'a single great canto' (Griffiths 2002, 78). The acrostic detected is thus an instance of poem- or book-initial acrostics, for which a number of parallels can be provided: see e.g. La Barbara 2006.

5 Hor. Carm. 3.2.1-4. 
guide is to determine whether the acrostic makes interpretative sense in the context in which it appears. ${ }^{6}$ In this case, the acrostic's harmony with the content of the stanza reduces considerably the possibility of mere coincidence. Horace emphasizes hasta by putting it in final position, and I cannot help myself from seeing Horace thereby accentuating a contrast between the favored weapons of the Roman and Parthian horsemen. The ablative singular form of arcu is thus readily to be explained as, besides being the only form to fit the stanza, suggesting this pairing with the analogously ablative singular hasta. The Parthians, we are implicitly told, wreak havoc with the bow; the Romans, in contrast, are to harry them with the spear. If this analysis is convincing, we may also disregard the following comment of the scholiast ps. Acro, supported by a modern interpreter: Parthos. Pro quibuslibet hostibus posuit. Species pro genere. ${ }^{7}$ It is understandable why commentators have felt compelled to understand the reference to Parthians in such a way. As they do not figure later in the poem, their appearance here seems somewhat arbitrary. But by adopting this line of reasoning, we fail to appreciate the perfect match between the acrostic and Horace's specific choice of Roman enemy.

The link between the acrostic and the remaining content of the stanza does not end here. Horace likely engages in word play between arcu and acri (v. 2). Such play is paralleled by Vergil, ${ }^{8}$ and moreover, acri too is in the ablative singular, further reinforcing the link. If this is accepted, we can then note as a result the stanza's highly elegant structure, which is surely deliberate. In this Alcaic stanza whose four verses consist of four words each, ${ }^{9}$ the three key words (acri, Parthos, and hasta) that relate most directly to the acrostic are placed as the second word of the second verse, the third word of the third verse, and the fourth word of the fourth verse. The vertical acrostic is confirmed by the diagonal sequence.

If this microscopic analysis has convincingly demonstrated the intentionality of the arcu acrostic, it might still be asked whether the acrostic has any

6 Thus, for example, the acrostic vina from v. 17-20 of the poem in question-not to mention the telestich esse of these same verses-is clearly accidental. Neither the stanza nor the poem at large has anything to do with wine. More difficult, perhaps, is the acrostic vi $\left(5^{-6}\right)$ or vim (5-7), which follows immediately upon our detected arcu acrostic. It is true that the word would fit the military context, and yet I have strong doubts that it is deliberate. It is not obvious, if we take vim, why the accusative form is present. And $v i$, besides presenting the same difficulty of why it appears in the ablative, has the compounded problem of being so short.

7 Cited, with approval, in Davis 1983, 14.

8 See Verg. A. 7.164 aut acris tendunt arcus and 9.665 intendunt acris arcus.

9 That is, if we do not accept Shackleton Bailey's unconvincing proposed emendation et aeque for amice in v. 1. See Shackleton Bailey 1985, 155-156. 
resonances beyond the stanza in which it occurs. I essay a partial, tentative answer. While, as far as I can tell, the acrostic is not evoked by the remainder of the second Roman Ode, the Regulus Ode would not be out of place as a candidate, insofar as Roman Odes " 2 et 5 sont intimement liées à la fois par le thème de la guerre extérieure et par celui de la Virtus". ${ }^{10}$ The second stanza (the first following the introductory praise of Augustus) of the Regulus Ode evokes jarringly, by contrast, the opening stanza of the second Roman Ode. No longer the puer fighting against the Parthians with his spear, the miles Crassi, having taken a barbarian wife, grows old serving under Parthian arms (consenuit socerorum in armis, 3.5.8). By hearkening back to the second Roman Ode, there may just be a hint that in serving under Parthian arms (in armis), emphasized at the end of the stanza, the failed Romans bear one weapon in particular, namely, the bow. ${ }^{11}$

\section{Bibliography}

Davis, G. (1983). Silence and Decorum. Encomiastic Convention and the Epilogue of Horace Carm. 3.2. ClAnt 2, pp. 9-26.

Griffiths, A. (2002). The Odes. Just Where Do You Draw the Line? In: A.J. Woodman and D.C. Feeney, eds., Tradition and Contexts in the Poetry of Horace, Cambridge, pp. 65-79.

Heyworth, S.J. (1995). Dividing Poems. In: O. Pecere and M.D. Reeve, eds., Formative Stages of Classical Traditions. Latin Texts from Antiquity to the Renaissance, Spoleto, pp. 117-148.

Jacques, J.-M. (1960). Sur un acrostiche d'Aratos (Phén., 783-787). REA 62, pp. 48-61.

Klingner, F. (1959). Q. Horati Flacci Opera. Leipzig.

La Barbara, S. (2006). Divinità occulte. Acrostici nei proemi di Ovidio e Claudiano. $M D$ 56, pp. $181-184$.

Lobel, E. (1928). Nicander's Signature. $C Q$ 22, p. 114.

Maleuvre, J.-Y. (1995). Les Odes Romaines d'Horace, ou un chef-d'œuvre ignoré de la cacozélie (presque) invisible. RBPh 73, pp. 53-72.

Nisbet, R.G.M., and Rudd, N. (2004). A Commentary on Horace. Odes Book III. Oxford.

Shackleton Bailey, D.R. (1985). Vindiciae Horatianae. HSPh 89, pp. 153-170.

Thomas, R. (2007). Horace and Hellenistic Poetry. In: S. Harrison, ed., The Cambridge Companion to Horace, Cambridge, pp. 50-62.

\footnotetext{
$10 \quad$ Maleuvre $1995,56$.

11 I am grateful to Vittorio Hösle and Mnemosyne's anonymous reviewer for their comments.
} 